\title{
calix[4]arene C-145 Effects on Plasma Haemostasis
}

Chernyshenko VO ${ }^{1 *}$, Korolova DS', Dosenko VE³, Pashevin DO³, Kalchenko VI², Pirogova LV', Chernyshenko TM1', Lugovska OE ${ }^{1,4}$, Kravchenko NA ${ }^{4}$, Makogonenko YM${ }^{1}$, Lugovskoy EV ${ }^{1}$ and Komisarenko SV ${ }^{1}$

${ }^{1}$ O.V. Palladin Institute of biochemistry NAS of Ukraine

${ }^{2}$ Institute of bioorganic chemistry and petro chemistry NAS of Ukraine

${ }^{3}$ O.O. Bohomolets Institute of physiology NAS of Ukraine

${ }^{4}$ Kyiv National Taras Shevchenko University, ESC Institute of biology

\begin{abstract}
Background: Calix[4]arene-methylene-bis-phosphonic acid C-192 and its sodium salt C-145 were shown to be efficient inhibitors of fibrin polymerization in vitro. In presented work we analyze the effects of calix[4]arene C-145 on haemostasis in vivo.

Methods: Parameters of coagulation system of rabbits intravenously injected with C-145 were monitored. We measured thrombin time (TT), ecamulin time (ET) and activated partial thromboplastin time (APTT), determined the levels of fibrinogen, prothrombin, protein $\mathrm{C}, \mathrm{PAl}-1$, monitored overall haemostatic potential before and after the injection.

Results: C-145 was administrated intravenously in the dose of $7.5 \mathrm{mg} / \mathrm{kg}$ of rabbit weight. 4 hours after the injection the thrombin time and activated partial thromboplastin time of rabbit's blood plasma were prolonged 2 and 1,5 times respectively. Such prolongation was observed after 24 hours as well. However, the total fibrinogen and prothrombin levels did not change. Parameters of fibrinolytic system (PAI-1, clot lysis half-time) and anticoagulant system (protein $\mathrm{C}$ ) remained unchanged.

Conclusions: Therefore we assumed that calix[4]arene C-145's effects on haemostasis consisted in selective inhibition of fibrin polymerization and formation of three-dimensional fibrin network.
\end{abstract}

Keywords: Calix[4]arene; Haemostasis; Antithrombotic drugs; Fibrin polymerization

Abbreviations: TT: Thrombin Time; APTT: Activated Partial Thromboplastin Time; ET: Ecamulin Time; PAI 1: Type 1 Inhibitor Of Plasminogen Activator; pNA: Para-Nitroaniline; PNPP: ParaNitrophenylphosphate; IV: Intravenous; HP: Haemostasis Potential; CP: Clotting Potential; FP: Fibrinolytic Potential; T-PA: Tissue-Type Plasminogen Activator, U-PA: Urokinase

\section{Introduction}

Calix[4]arene-methylene-bis-phosphonic acids are synthetic macrocyclic compounds obtained by cyclocondensation of parasubstituted phenols and formaldehyde [1]. Aromatic rings of calix[4]arenes form a lipophilic 'cup', an interface tailored to handle macromolecules through hydrogen bonds, hydrophobicity or electrostatic interactions. Modified calix[4]arenes are able to bind specifically to high-molecular compounds [1]. Earlier we found two of calix[4]arene-methylene-bis-phosphonic acids which specifically inhibit construction of the blood clot's carcass, 3-D fibrin network [2]. In particular, calix[4]arene-tetra-methylene-bis-phosphonic acid (C192) and its sodium salt (C-145) specifically inhibited the first stage of fibrin polymerization, the formation of protofibrils $\left(\mathrm{IC}_{50}=0.5 \cdot 10^{-6}\right.$ and $\mathrm{IC}_{50}=2,5 \cdot 10^{-6}$ respectively). Structure of C-145 is shown on (Figure 1 ). Further research in vitro did not reveal any influence of these calix[4] arenes on platelets and red blood cells, as well as on Factor X activation, prothrombin, and protein C [3].

The anti-polymerization properties of C-192 and C-145 allowed us to consider them as potential compounds for the design a novel class of antithrombotic agents, which are able to inhibit specifically blood clot formation through the fibrin polymerization inhibition. To introduce a medicinal preparation, however, it is necessary to study its effects not only in vitro, but also in lab animals.
The present work was aimed to study the effect of intravenously injected C-145 on rabbit's haemostasis.

\section{Materials and Methods}

\section{Materials}

Thrombin, thromboplastin, APTT-reagent, plasminogen, tissue plasminogen activator (tPA), were purchased from Sigma-Aldrich (US). Chromogenic substrates S2236 (pyro-Glu-L-Pro-L-Arg-pNA), S2308 (H-D-Phe-Pip-Arg-pNA) was purchased from Chromogenix (Sweden), ADP from Tekhnologia-standard (Russia); AntiPAI-1 rabbit polyclonal IgG; Goat anti-rabbit IgG $(\mathrm{H}+\mathrm{L})$ alkaline phosphatase conjugate (Sigma, US). Prothrombin activator (ecamulin) was purified from the crude venom of Echis multisquamatis according to [4].

\section{Methods}

Sample of Calix[4]arene C-145 was dissolved in $0.9 \% \mathrm{NaCl}$ solution to the final concentration $15 \mathrm{mg} / \mathrm{ml}$ and was injected in the marginal ear vein of rabbit in the dose of $7.5 \mathrm{mg} / \mathrm{kg}$ using Wenflon catheter (Becton Dickinson, USA), G22 $(0.8 \mathrm{~mm})$. The animal research protocol for that study was approved by the Institutional Animal

*Corresponding author: Volodymyr Chernyshenko, Protein Structure and Functions Department, Palladin Institute of Biochemistry, 9 Leontovych Str., Kiev, 01601, Ukraine, Tel: (044) 234 5974; Fax: (044) 279 6365; E-mail: bio.cherv@gmail.com

Received July 24, 2015; Accepted August 12, 2015; Published August 15, 2015

Citation: Chernyshenko VO, Korolova DS, Dosenko VE, Pashevin DO, Kalchenko VI, et al. (2015) Calix[4]arene C-145 Effects on Plasma Haemostasis. Pharm Anal Acta 6: 406. doi:10.4172/21532435.1000406

Copyright: (c) 2015 Chernyshenko VO, et al. This is an open-access article distributed under the terms of the Creative Commons Attribution License, which permits unrestricted use, distribution, and reproduction in any medium, provided the original author and source are credited. 


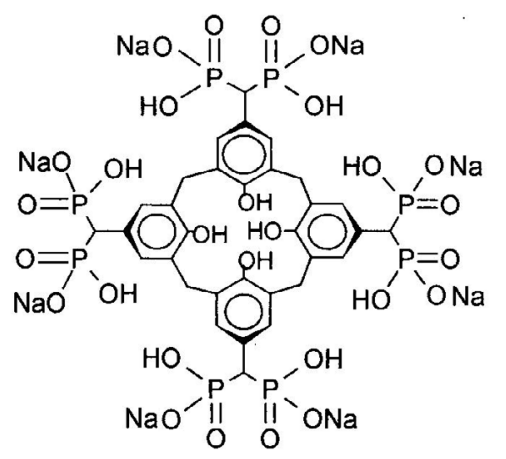

Figure 1: Structural model of C-145 - sodium salt of calix[4]arenemethylene-bis-phosphonic acid.

and Care Committee of Palladin Institute of Biochemistry of NAS of Ukraine (February 4, 2014, protocol number 1).

Blood samples were collected using Wenflon catheter (Becton Dickinson, USA), G22 (0.8 $\mathrm{mm}$ ) before the injection and after 2, 4 and 24 hours after injection. $3.2 \%$ Sodium Citrate added immediately after collection to whole blood in 1:9 ratio was used as an anticoagulant.

Blood plasma was prepared from citrated blood by centrifugation at $1200 \mathrm{rpm}$ during $30 \mathrm{~min}$.

Activated partial thromboplastin time (APTT) was performed according to the following procedure. $0.1 \mathrm{ml}$ of blood plasma was mixed with equal volume of APTT-reagent and incubated during 3 minutes at $37^{\circ} \mathrm{C}$. Then the coagulation was initiated by adding of 0.1 $\mathrm{ml}$ of $0.025 \mathrm{M}$ solution of $\mathrm{CaCl}_{2}$. Clotting time was monitored by the Coagulometer Solar CGL-2410 (Belorussia).

Thrombin time was performed by adding of $0.125 \mathrm{NIH} / \mathrm{ml}$ of thrombin to the mixture of blood plasma $(0.1 \mathrm{ml})$ with equal volume of $\mathrm{CaCl}_{2}$ solution $(0.025 \mathrm{M})$. Results were presented as the ratio of blood plasma clotting time of experimental animal to the control clotting time. Clotting time was monitored by the Coagulometer Solar CGL2410 (Belorussia).

Fibrinogen concentration in the blood plasma was determined by the modified spectrophotometric method. Blood plasma $(0.2 \mathrm{ml})$ and PBS $(1.7 \mathrm{ml})$ were mixed in glass tube. Coagulation was initiated by the addition of $0.1 \mathrm{ml}$ of thrombin $(2 \mathrm{NIH} / \mathrm{ml})$. To avoid fibrin crosslinking $0.1 \mathrm{ml}$ of $40 \mathrm{mM}$ monoiodacetic acid was added to the sample. Mixture was incubated during $30 \mathrm{~min}$ at $37^{\circ} \mathrm{C}$. The fibrin clot was removed and re-solved in $5 \mathrm{ml}$ of $1.5 \%$ Acetic acid. The concentration of protein was measured using spectrophotometer SF-2000 (Russia) at $280 \mathrm{~nm}(\varepsilon=1.5)$.

Prothrombin level was measured using ecamulin test (ET). Ecamulin is the prothrombin activator from Echis multisqumatis snake venom that activates prothrombin and all his inactive forms [5]. So it allowed us to determine total prothrombin level. Thrombin generation was measured by chromogenic substrate assay using thrombinspecific S2238. Results were presented as ecamulin (EI) index, that was calculated by formula: $\mathrm{EI}=\mathrm{Ap} / \mathrm{An}$; $\mathrm{PI}=\mathrm{Ap} / \mathrm{An}, \mathrm{An}-$ normal rabbit's blood plasma thrombin activity; Ap - calix[4]arene-treated rabbit's blood plasma thrombin activity.

Protein $\mathrm{C}$ level was determined using the activator of protein $\mathrm{C}$ according to [6]. The generation of activated protein $C$ was measured by chromogenic substrate assay using specific chromogenic substrate S2236.
Overall haemostatic potential was studied by monitoring turbidity during clot formation and lysis. The mixture of $12 \mu \mathrm{l}$ of citrated human plasma in 0.05 M HEPES-buffer pH 7.4 (0.15 M NaCl, $\left.5 \mathrm{mM} \mathrm{CaCl}_{2}\right), 75$ $\mathrm{NIH} / \mathrm{ml}$ of tPA was clotted by $5 \mu \mathrm{l}$ of thromboplastin and turbidity was monitored at $350 \mathrm{~nm}$ at room temperature as described in [7].

PAI-1 was detected using ELISA according to [8]. Mixture was contain $2 \mu$ of blood plasma in $0.2 \mathrm{ml}$ of TBS. Polyclonal anti-PAI-1 antibody and Goat anti-rabbit IgG conjugated to alkaline phosphatise were used for the detection. PNP formed after PNPP cleavage by alkaline phosphatase was determined at $405 \mathrm{~nm}$ using multiplate reader Multiscan EX

Statistical data analysis was performed using Microsoft Excel. All assays were performed in series of three replicates and the data were fitted with standard errors using "Statistica 7".

\section{Results}

To evaluate the possible effect of the calix[4] arenes on haemostasis in vivo, healthy rabbits were intravenously injected with $1 \mathrm{ml}$ of C-145 in saline solution $(7.5 \mathrm{mg} / \mathrm{kg})$. The quantity amounted to $1.5 \% \mathrm{LD} 50$. as determined for rats injected intraperitoneally [9]. As the total volume of an adult rabbit's blood is about $250 \mathrm{ml}$ [10], the level of C-145 was about $0.06 \mathrm{mg} / \mathrm{ml}(46 \mu \mathrm{M})$. In vitro, this prolonged APTT in blood plasma 1.7-fold $(\mathrm{P}=0.05)$ [9].

Four hours after injection of C-145, APTT of the rabbit's blood plasma grew 1.5-fold and TT twice, and they remained so for 24 hr (Figure 2). TT was affected more because fibrin formation and polymerization are initiated directly by exogenous thrombin, while in APTT blood coagulation happens indirectly through the intrinsic pathway.

Therefore the anti-polymerization effect of C-145 shown in vitro also occurred in the intravenously injected rabbits. C-145 prolonged coagulation time in both basic tests (APTT \& TT) with statistical significance, albeit unequally: TT grew 1.33 times more $(\mathrm{P}=0.05)$. It can be explained by APTT incorporating the whole coagulation cascade, while in TT we tested the influence of C-145 upon polymerization of fibrin originating in the last stage of the cascade: the fibrinogen + thrombin reaction.

We also studied an effect the calix[4] arene had on the other blood coagulation components. Main proteins of the system, fibrinogen and prothrombin, were not influenced by C-145 injection (Figure 3). This supports our conclusion about its selective and focused action only upon the fibrin polymerization stage in the coagulation cascade without any influence upon other protein factors [3].

The state of anti-coagulation branch of haemostasis system following C-145 injection was analyzed by protein C quantification in plasma after 4 and $24 \mathrm{hr}$.

It was shown that $4 \mathrm{hr}$ after the injection of $\mathrm{C}-145$, protein $\mathrm{C}$ level didn't practically change (Figure 4). However, later it decreased by 15 $25 \%$. That the deficit increases after a whole $24 \mathrm{hr}$, points that C-145 doesn't have a direct impact on the anti-coagulation branch of the system [11].

A number of anti-coagulative preparations are known to coinfluence the fibrinolytic system [12]. It is known that plasminogen is activated on fibrin. As C-145 interacts with monomeric fibrin, preventing its polymerization, we had to study its effect on plasminogen activation, plasmin activity and overall fibrinolysis in plasma [13]. 


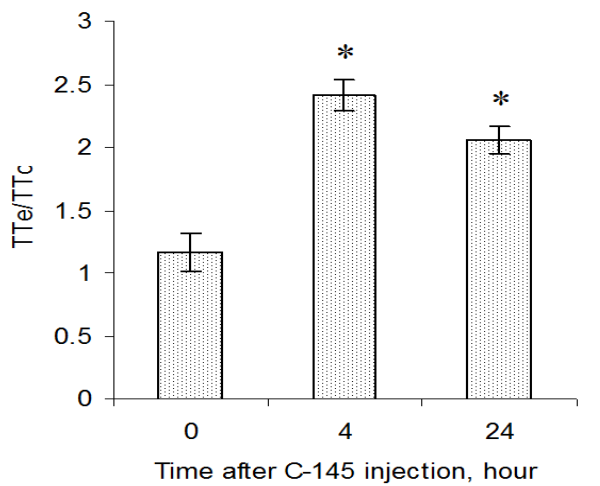

A.

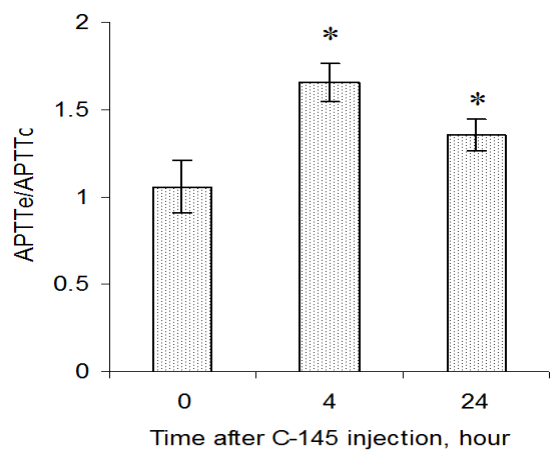

B.

Figure 2: Thrombin time (TT) and activated partial thromboplastin time (APTT) of rabbit's blood plasma before $(0)$ and after intravenous administration of C-145. A - TT, B - APTT. The graphs show the ratios of blood coagulation time following 0.4 and $24 \mathrm{hr}$ (TTe, APTTe) to the initial blood coagulation time (TTc, APTTC). * - Significant at $p<0.005, n=3$.

The main direct evidences for the activation of fibrinolytic system are the rise in plasmin activity in blood plasma and the generation of plasminogen activator inhibitors (PAI-1, a2-antiplasmin) [14]. To reveal possible causes of the fibrinolysis inhibition that was seen after the C-145 injection, we measured PAI-1 in rabbit plasma $[15,16]$. It remained constant 4 and $24 \mathrm{hr}$ after the injection, there was no significant difference between the control and the experiment (Figure $5)$.

For a combined analysis of the blood clot's formation and its hydrolysis we measured haemostasis potential (HP), clotting potential (CP) and fibrinolytic potential (FP) in plasma before the injection and 2 and $4 \mathrm{hr}$ after. The coagulation was initiated by thromboplastin, together with exogenous tPA to determine HP and FP [17].

After the injection, the HP, CP and FP in plasma were 11.0 -, 12.2- and 9.0-fold lower, respectively (Table 1). These data point to the very strong impact C-145 has on the plasma's clotting ability. On the other hand, it does not significantly influence the balance between the coagulative and fibrinolytic components of haemostasis, calculated as the FP/CP ratio (Table 1). This lets us to suppose that the inhibition FP is caused not by C-145's action on fibrinolysis, but by the reduction in size of the hydrolyzed fibrin clot.

\section{Discussion}

Antithrombotic preparations act by rapid and controlled decrease of the activity of blood coagulation. The main criteria of their quality are efficiency and lack of contraindications. They can be classified into anti-coagulants, which inhibit clotting on various stages, and profibrinolytics, which speed up the fibrin clot's destruction (t-PA, u-PA, streptokinase) $[18,19]$. Most anti-coagulants act directly upon thrombin (dabigatran) [20], factor Xa (rivaraxaban) [21], factors VIIIa and $\mathrm{V}$ (drotrecogin) [22], blocking the clotting cascade on the stages of factor $\mathrm{X}$ activation or prothrombin to thrombin and fibrinogen to fibrin transformations. A possibility of the use of anti-thrombotics directly acting upon the last link of blood clot formation, namely
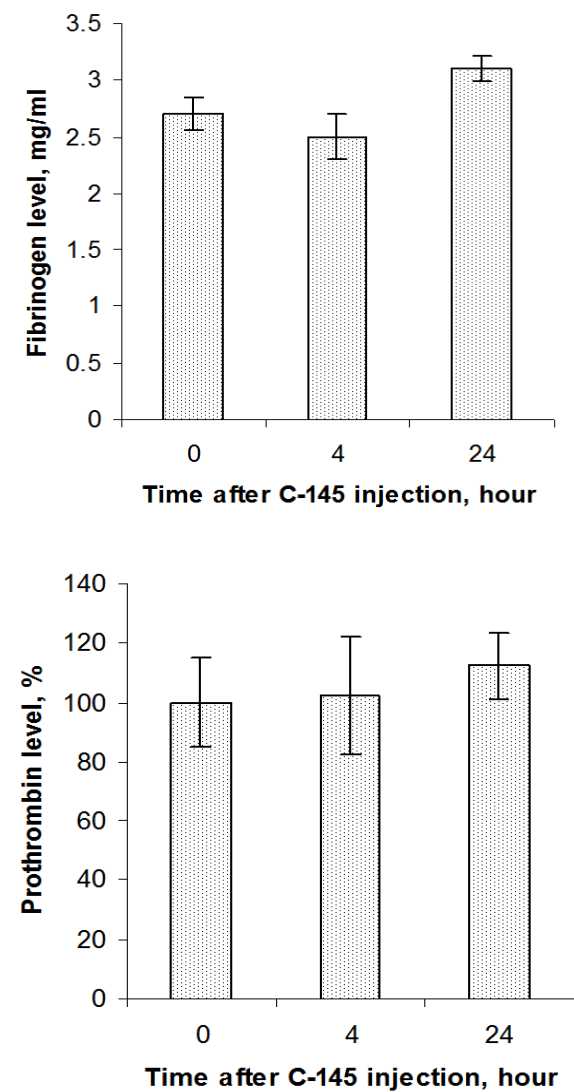

Figure 3: Fibrinogen (A), mg/ml, and prothrombin (B), \%, levels in rabbit plasma before (0) and after 4 and $24 \mathrm{hr}$ after intravenous administration of C-145.

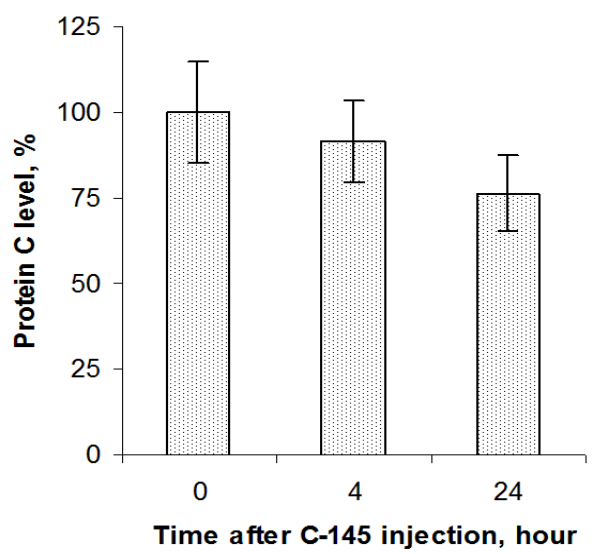

Figure 4: Protein C level, \%, in plasma of experimental rabbits before $(0)$ and after 4 and $24 \mathrm{hr}$ after intravenous administration of C-145. 


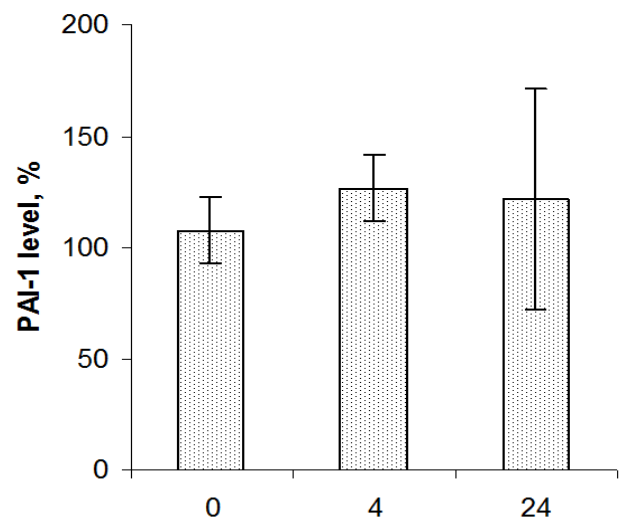

Time after C-145 injection, hour

Figure 5: PAl-1 level in rabbit plasma following intravenous administration of C-145 after 0.4 and $24 \mathrm{hr}$.

\begin{tabular}{|l|l|l|l|l|l|}
\hline Time after injection, $\mathbf{h r}$ & $\mathbf{C P}$ & HP & FP & CP/FP & Clot half-life time, s \\
\hline 0 & 91.8 & 64.9 & 26.9 & 0.29 & 740 \\
\hline 2 & 53.4 & 41.4 & 12 & 0.22 & 740 \\
\hline 4 & 8.8 & 5.7 & 3.1 & 0.35 & 550 \\
\hline
\end{tabular}

Table 1: Clotting potential (CP), haemostasis potential (HP), fibrinolytic potential (FP) and ratios of Clotting and Fibrinolytic potentials (CP/FP) in rabbit plasma before $(0)$ and 2 and $4 \mathrm{hr}$ after an IV injection of C-145.

fibrin polymerization, is a hot topic of research [23,24]. In particular, decreasing of the fibrin polymer density was attempted through adding silver nano-particles [25] or inhibiting peptides (e.g., GPRP), conjugated with albumin [26].

In this respect this calix[4]arene, being low-molecular and potentially non-immunogenic organic molecule may turn out to be potentially valuable highly specific antithrombotic agents, inhibiting fibrin polymerization by blocking the A polymerization site [2]. The effect was revealed to be quite significant in vivo in rabbits intravenously injected with C-145. Meanwhile it had no impact upon prothrombin and fibrinogen levels in plasma and no significant effect upon the activity of the fibrinolysis system and PAI-1 levels.

Therefore, we found a specific anti-polymerisation effect of the calix [4] arene C-145 in vivo comparable to effects in vitro. The substance did not notably influence the total level of prothrombin, fibrinogen, activity of the anti-coagulative and fibrinolytic systems and the balance between the fibrin formation and digestion.

The results allow us to consider calix[4]arene C-145 as a potential anti-thrombotic agent with narrow effect range. The next stage of research in vivo should focus on its impact upon the vascular-platelet link of haemostasis.

\section{Addendum}

All authors contributed this work equally. Chernyshenko V.O., Korolova D.S., Pirogova L.V., Kravchenko N.A., Lugovska O.E., Chernyshenko T.M. performed diagnostic tests of rabbits' blood plasma after the injection of calix[4]arene C-145. Kalchenko V.I. was a constructor of calix[4]arene C-145 samples. Dosenko V.E. and Pashevin D.O. were in aim for the animal studies. Makogonenko Y.M., Lugovskoy E.V. and Komisarenko S.V. contributed to the work on all stages and also developed an ideology of experiments and interpreted the data obtained.

\section{References}

1. Rodik RV, Boyko VI, Kalchenko VI (2009) Calixarenes in bio-medical researches. Curr Med Chem 16: 1630-1655.

2. Lugovskoy EV, Gritsenko PG, Koshel TA (2011) Calix[4]arene methylenebisphosphonic acids as inhibitors of fibrin polymerization. FEBS Journal 278: 1244-1251.

3. Cherenok SO, Yuschenko OO, Gritsenko PG, Lugovskoy EV, Koshel TA et al. (2010) Synthesis of calixarene-methylenbisphosphonic acids and their influence on fibrin polymerization. 18th International Conference on Phosphorus Chemistry. Wroclaw 72

4. Solovev DA, Platonova TN, Ugarova TP (1996) Isolation and characteristics of ekamulin--a prothrombin activator from multiscaled viper (Echis multisquamatus) venom. Biokhimiya 61: 1094-1105.

5. Korolova DS, Chernyshenko VO, Hornyts'ka OV, Platonova TM (2009) Influence of prothrombin cleavage products on platelet activation and aggregation. Ukr Biokhim Zh 81: 58-65.

6. Gornitskaia OV, Platonova TN (2003) Isolation and properties of the protein $\mathrm{C}$ activator from Agkistrodon halys halys venom. Biomed Khim 49: 470-478.

7. Rublenko AM, Urvant LP, Makogonenko leM, Platonova TM, Tsap Plu, (2011) Effect of protein $\mathrm{C}$ activator on overall haemostasis potential in donor and hip arthroplasty patient plasma. Ukr Biokhim Zh 83: 32-39.

8. Selected methods for antibody and nucleic acid probes / Cold Spring Harbor Laboratory Press. - USA, 1993.

9. Komisarenko SV, Kosterin SO, Lugovskoy EV, Kalchenko VI (2013) Calixarene methylene bisphosphonic acids as promising effectors of biochemical processes. Ukr Biokhim Zh 85: 32-39.

10. Gorska $P(2000)$ Principles in laboratory animal research for experimental purposes. Med Sci Monit 1: 171-180.

11. Borgel D, Bornstain C, Reitsma PH, Lerolle N, Gandrille S, et al. (2007) A comparative study of the protein $\mathrm{C}$ pathway in septic and nonseptic patients with organ failure. Am J Respir Crit Care Med 176: 878-885.

12. Fareed J, Bacher P, Messmore HL, Walenga JM, Hoppensteadt DA, et al (1992) Pharmacological modulation of fibrinolysis by antithrombotic and cardiovascular drugs. Prog Cardiovasc Dis 34: 379-398.

13. Yakovlev S, Makogonenko E, Kurochkina T, Nieuwenhuizen W, Ingham K, et al. (2000) Conversion of fibrinogen to fibrin: mechanism of exposure of tPAand plasminogen-binding sites. Biochemistry 39: 15730-15741.

14. Potempa J, Korzus E, Travis J (1994) The serpin superfamily of proteinase inhibitors: structure, function, and regulation. J Biol Chem 269: 15957-15960.

15. Juhan-Vaguea I, Moermana B, De Cocka F, Aillauda MF, Collen D (1984) Plasma levels of a specific inhibitor of tissue-type plasminogen activator (and urokinase) in normal and pathological conditions. Thrombosis Research 33: 523-530.

16. Fay WP, Murphy JG, Owen WG (1996) High concentrations of active plasminogen activator inhibitor-1 in porcine coronary artery thrombi. Arterioscler Thromb Vasc Biol 16: 1277-1284.

17. He S, Antovic A, Blomback M (2001) A simple and rapid laboratory method for determination of haemostasis potential in plasma. II. Modifications for use in routine laboratories and research work. Thromb Res 103: 355-361.

18. Sikka P, Bindra VK (2010) Newer antithrombotic drugs. Indian J Crit Care Med 14: $188-195$

19. Weitz JI, Eikelboom JW, Samama MM. New antithrombotic drugs. Chest 2012;141: 120-151.

20. Ageno W., Gallus AS, Wittkowsky A, Crowther M, Hylek EM, et al. (2012) Ora anticoagulant therapy: antithrombotic therapy and prevention of thrombosis, 9th ed: American College of Chest Physicians evidence-based clinical practice guidelines. Chest 141: 44-88.

21. Kubitza D, Becka M, Wensing G, Voith B, Zuehlsdorf M (2005) Safety, pharmacodynamics, and pharmacokinetics of BAY 59-7939 - an oral, direct Factor Xa inhibitor - after multiple dosing in healthy male subjects. Eur $\mathrm{J}$ Clin Pharmacol 61: 873-880.

22. Abraham E, Laterre P-F, Garg R, Trzaskoma BL, Correll NL, et al. (2005) Administration of Drotrecogin Alfa (Activated) in Early Stage Severe Sepsis 
Citation: Chernyshenko VO, Korolova DS, Dosenko VE, Pashevin DO, Kalchenko VI, et al. (2015) Calix[4]arene C-145 Effects on Plasma Haemostasis. Pharm Anal Acta 6: 406. doi:10.4172/21532435.1000406

Page 5 of 5

(ADDRESS) Study Group Drotrecogin alfa (activated) for adults with severe sepsis and a low risk of death. N Engl J Med 353: 1332-1341.

23. Weisel JW, Litvinov RI (2013) Mechanisms of fibrin polymerization and clinical implications. Blood 121: 1712-1719.

24. Chernysh IN, Nagaswami Ch, Purohit PK, Weisel JW (2012) Fibrin clots are equilibrium polymers that can be remodeled without proteolytic digestion. Scientific Reports 2: 1-6.
25. Shrivastava S, Singh SK, Mukhopadhyay A, Sinha AS, Mandal RK, et al. (2011) Negative regulation of fibrin polymerization and clot formation by nanoparticles of silver. Colloids Surf B Biointerfaces 82: 241-246.

26. Watson JW, Doolittle RF. Peptide-derivatized albumins that inhibit fibrin polymerization. Biochemistry 50: 9923-9927. 